\title{
The Cognitive Basis of Stupidity
}

\author{
James F Welles*
}

Free lancer, USA

Submission: November 14, 2017; Published: January 30, 2018

*Corresponding author: James F Welles, PO Box 17, East Marion, New York, USA, Tel: 954531 5382; Email: JWelles103@aol.com

Abstract

Human culture may be viewed in terms of a number of interacting component systems [1], each of which caters to a basic need. First and foremost culture is a belief system; there is invariably some religious commitment to a higher order of presumed powers or conjured beings. There is a subtle hint of stupidity as a common element which unifies culture into a disintegrating whole. For the past two hundred years, social scientists have been trying to impose some order of logic on the actions and interrelationships of these systems. Perhaps it is time to consider the very real possibility that such order and logic are, like astrological figures, invented and both the systems and their interactions are illogical, inconsistent and maladaptive to the point that culture may be characterized as stupid.

Keywords: Human culture; Religious commitment; Stupidity; Social scientists; Illogical

\section{Introduction}

The nature, range and intensity of sacred religions/secular cognitive systems may differ, but having a belief system is a human universal, and cultural is the social mechanism for creating and maintaining the various religious systems of the world. Born of myths attempts of primitive people to make sense of their plights and warn descendants of potential dangers [2] religion was originally directed toward supernatural spirits which presumably influenced natural events, with the gods invented for social control [3] and religion a deliberate imposture devised by some cunning man for political ends [4]. Now, belief systems are also directed toward superhuman principles which shape our cultural institutions. Whether supernatural or superhuman phenomena be revered, the mode of religious belief is the same, and it is this process of belief the defining feature of schemas which determines the nature of both humanity and stupidity.

The psychological basis for religion is that people are disposed to worship what they cannot control. (This disposition may be represented by the formula: Control $\mathrm{x}$ Belief $=\mathrm{K}$ ) People also like to think they enter into some kind of reciprocal relationship with the incomprehensible if a system of belief, observance and ritual is established. This may provide a one sided, imbalanced reciprocity, but it gives people the feeling that they have at least some input into the cosmic schema. In more mundane matters, people may literally «Believe in» (worship) their cultural institutions (the government, economisms, etc.) [5], particularly if and when they feel they have no control over such organizations and entities as many justifiably feel they do not in the modern world.
One real psychological benefit to having belief systems and their supporting rituals is that both can serve to reduce anxiety in times of crisis: Belief systems provide a sense of control, and rituals provide a culturally acceptable means of action. In matters of ill health, the success of curers can be explained by the real effectiveness of medicinal treatment, the fact that some people recover anyway [6], and also by the fact that stress and anxiety are reduced for some patients who really believe in the medicine man and his little rituals [7]. Thus, recovery may be enhanced even if the specific treatment is medical nonsense.

For example, in some primitive societies, a belief in the malevolent dead provides a theory of disease. It offers both an explanation of cause (the actions of evil spirits) and a means of prevention (calling on friendly spirits). In the absence of any really effective medical means of coping with illness, such a belief and its attendant rituals permit people to face an otherwise bewildering experience with some confidence, and this, itself, can reduce the psychological distress accompanying an illness [8]. If this is a short term gain, and it indeed may be, there may also be a long term loss, if such a belief system and its sustaining rituals prevent people from finding a real cure or means of preventing disease.

In general, religious systems are most conspicuous among peoples who are intensely dependent upon nature and have limited technical means for controlling it [9]. This is the condition that originally led fantasy to add a spiritual element to the natural world, making the supernatural. This process was typically human people rarely being content to generalize from 


\section{Global Journal of Intellectual \& Developmental Disabilities}

just the data at hand when some more can be invented to dress up reality a bit. In sophisticated societies, people have come to misdirect their religious fervor toward their own cultural systems and even themselves. Although this may promote group cohesion and improve morale, it can inhibit both learning about and adaptation to reality. Although, in moderation, this trade off can be adaptive, by its very nature, it tends to excess and becomes maladaptive because it is a cultural phenomenon, and culture is, inherently, a positive feedback mechanism. (E.g., technology begets more technology; patriotism more patriots.)

Along with beliefs, which all people have, humans also must have answers. The questions are universals: Who are we? [10]. Where did we come from? Where are we going? When will we get there? The answers form an ideology, which masks the interests of the dominant class and presents them as the inevitable workings of history [11]. When valid answers are not available, they are manufactured by the schema because having an answer, even if it is wrong, is apparently more comforting than having none at all. One seldom hears the entropically futile, «We are helpless and hopeless and doomed to a pointless existence by indifferent fate [12]» or, to rephrase the Bard, 'Life is a tale told by an idiot, full of words and actions, signifying stupidity' or the even more prosaic, «We don't know what we're doing». If and when such answers are offered those accepting them are not much inspired nor well disposed to pass them on. On the contrary, most contrived answers tend to be self serving and designed to promote beliefs in both the supernatural and the fallible village elders (i.e., priests) who provided them.

The role of «Answer man» is played by the priest a religious or secular expert who serves as an intermediary between the public and the supernatural spirits or superhuman institutions in which the people believe. The priest is really sort of a public relations agent for the Almighty or the mere mighty. His job is to pass off reality in the best possible light and gloss over minor disasters, plagues, wars, etc. God and secular leaders get credit for anything good that happens, while any bad events are attributed to evil powers which serve as handy foibles for the priests and those they represent.

Worse yet, priests are often responsible for perverting noble ideals into ignoble means by the human devices of labeling and «Interpretation». By these methods, a code of beliefs is adapted to the real impending needs and circumstances of society. Interpretation, especially, permits faith to continue, even when necessity clearly demands that behavior contradict ideals. For example, American ideals have twice been trampled by «Real» Americans indulging in witch hunts for Communist heretics during the postWorld War Red Scares. In a similar vein, real Christians are supposed to love their fellow man, but «Man» is commonly interpreted to mean «People like us» [13].

It is sad indeed to note that the teachings of great religious leaders have so often been interpreted to justify some of the most barbaric, «Inhuman» attitudes and acts in history [14]. An example of such a degraded ideal was provided by the Crusaders, who slaughtered infidels (and often the devout as well) in the name if not the spirit of Christ. It really is some kind of perverse miracle that the image of peace, purity and principle personified by Jesus could foster such fanaticism in his followers that his commandment to live in love could be so totally lost specifically on the cognitive dissonanced faithful [15].

As for Muhammad, he was an orphan and shifty character who was a compound of considerable vanity, greed, cunning, self deception and sincere religious passion. Right at the beginning, he declared that Islam was not to be a religion of miracles, so it became one of contemplation and analysis continuing the Greek veneration of statics and perfect forms like circles. Its internal contradictions are based on the "Peace verses", which were composed when he was powerless and the "War verses", which were created when he had some muscle behind him. Its intellectual limitations are traceable back to the late 11th century when the Muslim clergy began a concerted onslaught against all teachings that did not derive from either the Koran or sayings of the Prophet and even some lessons that did. Fanaticism found expression in the early 12th century in the directive of Ibn Tumart, who condemned the Berber Almoravids for their effeminate form of Islam and urged his followers to "Kill them wherever you may find them [16-21]."

The fundamental contradiction which plagued Islamic leaders was a universal for all political leaders-they cannot rule according to the pious rules for the many [22]. Most rulers spend most of their time trying to rationalize what they have to do to stay in power, and the terminology for their psychic cover charcterizes the shibboleths they espouse to their devoted followers.

Although for its first thousand years-while Europe wallowed in the Dark Ages Islam was open to the knowledge and philosophies of the lands it conquered to the point that it propagated and disseminated them. At first, scholars limited themselves to determining exactly what Mohammed said or at least meant. Their methodology was strictly defined in five progressive steps the last of which was Ijtihad independent reasoning [23] except that it was not that independent: It had to conform to scripture. By 1700, scholars agreed with themselves that everything had been worked out, so the people no longer needed free and independent thought at all. They just had to obey the law [24].

In a culture in which church and state are one, there is little to distinguish law from religion. There are five schools of law, all of which are accepted by all Muslims, but for religious scholars, there is only one ultimate goal-to become an alim, or learned one. This honor is achieved only by internalizing accepted Muslim doctrine [25]. This constitutes an ultimate in post-feed systems in that questioning it is not only impossible but unthinkable.

As Islam expanded, other intellectuals of note-the philosophers tried to make sense of the natural and cultural 


\section{Global Journal of Intellectual \& Developmental Disabilities}

worlds being discovered. Baghdad became the intellectual center of the world as Muslim scholars became the first to integrate Greek philosophers with Hindu mystics and Indian medicine with Chinese cosmologies [26]. God remained unknowable to the puny human mind, but reason could lead to truth without theological revelation [27]. Scholars reveled in calculations, its artists and mathematicians fused to produce geometric patterns with its ultimate intellectual/spiritual state being one of unearthly ecstacy.

As for science, determinism reigned consistent with the Qur'an, astronomy flourished but anatomy floundered, as representations of the human body were forbidden-while creating one of Muhammad is a capital offense [28]. As a state religion, Islam now constitutes one of the most intense forms of all cultural stupefication. It self righteously concentrates human energy and promotes conformity in both belief and behavior [29] by forbidding rational speculation as well as by concealing the truth.

In the early 16th century, Muslim scholars interpreted knowledge to mean only knowledge of religion and that other information was un-Islamic [30]. Devotees turned their collective backs on the printing press as potentially sacrilegious [31] if not fatal in that in 1515, Sultan Selig I threatened anyone using a printing press with death [32]. Islam's House of Wisdom truly and irrevocably collapsed in a rage of piety [33] and hatred, but Muslims marched and fought onward sans wisdom, knowledge and compassionate understanding.

In the 18th century, preacher Muhammad Abd Al Wahhab declared war on Greek philosophy and Muslims who disagreed with him and urged a return to the austerity created by the Prophet in 622. His followers rejected secular modernism, called for the imposition of Muslim law, restricted the role of women and aspired to return to the 7th century [34]. In extreme cases, it becomes an obsessivecompulsive personality disorder characterized by a rigidly stubborn inflexibility in its rules and morality. You cannot theorize or hypothesize otherwise [35]. Indeed, the word "Islam" means submission [36]. As our contemporary Imam Anwar Awalaki trenchantly noted, a binding duty is a binding duty: Jihad is total war-no questions asked. Allah is the answer, and as Muhammad (ca. 600) so clearly put it, he was sent to earth until Allah alone is worshiped [37] and Muslims rule the world [38]. Have a nice day.

With a description that could serve for the followers of any venerable religion, Muslim scientist alRazi, in the most violent antireligious polemic of the middle Ages [39], held his brethren had originally been duped by authority figures-deluded by bearded goats who recounted lies, senseless myths and hearsay [40]. Further, he denigrated the Koran for failing to be a true allegorical mythology while being full of contradictions but containing no useful information or explanations [41]. In this regard, he was not just anti Islam nor anti Koran: he thought all "Revealed religions" were disasters because they led religious leaders to be cruel, despotic and belligerent [42] e.g., our contemporary rabid, self righteous, terrorist supporting Muslim clerics as well as our rightwing Klanish, Christian extremists.

Any doubt about this should be dispelled by the following quotation of theologian Winston Churchill: "How dreadful are the curses which Mohammedanism lays on its votaries! Besides the fanatical frenzy, there is the fearful fatalistic apathy. The effects are apparent in many countries. Improvident habits, slovenly systems of agriculture, sluggish methods of commerce, and insecurity of property wherever the followers of the Prophet rule or live. A degraded sensualism deprives this life of its grace and refinement: the next of its dignity and sanctity. The fact that in Mohammedan law every woman must belong (sic) to some man as his absolute property must delay the final extinction of slavery until the faith of Islam has ceased to be a great power among men the influence of the religion paralyses the social development of those who follow it. No stronger retrograde force exists in the world [43].

To Martin Luther's credit, in 1542, he called for the distribution of the Koran throughout Christiandom but not out of respectful tolerance. He felt nothing else would bring more grievous harm to Mohammed than to bring his teaching to the light of day. Thus would Christians learn how cursed, abominable and desperate a book it is-unlike the Bible full of lies, fables and abominations that believers thereof conceal and gloss over. To harm Muslims and vex the devil, he called for the righteous to "Set the book free and don't withhold it" [44].

This is all the sadder because Mohammed basically wanted to take his brethren away from the corrupting urban influences of his time and place and back to the good old tribal values when people looked after each other and cared for their camels and women. His message had nothing to do with an afterlife or heaven but did hold everyone accountable to Allah for the sum of their actions. Unfortunately, his revelations were so extensive that they lent themselves not only to interpreters in later ages but fortunately also to reformers, who now are trying to drag Muslims kicking and praying into the seventeenth century.

Even when they succeed, there remains something medieval -or certainly closedminded-about Islam. The faithful do not subject their sacred if ambiguous creed to interpretation. Indeed, as Islam's answer to Jefferson and Voltaire, Muslim preacher and scholar Abdal Wahhab spent most of the 18th century burning books and beheading those with whom he disagreed [45]. More to the point, in the Western tradition, there is a separation between church and state; in the Muslim tradition, the mosque and state are one. This, in turn, is because Christianity is designed to promote salvation of the individual where as Islam is directed toward creating the ideal community [46]. Thus, there is an reconcilable, bridgeable gap between the systems: All we need is an ideal community in which individual souls are saved. In our current age of radicalization, stalwarts maintain Islam is brought to earth on the point of a sword whether people like it or 


\section{Global Journal of Intellectual \& Developmental Disabilities}

not, and we are engaged in a cultural war of Islam vs. Christianity [47] whether we admit it or not.

The goal of the militant Muslims is to destroy our belief system [48] which we might characterize as Judaic Christian, capitalistic democracy. To this end, jihadists think they can terrorize us into submission i.e., Islam. Our best counterstrategy is not based on bomb sniffing dogs or background checks but publicity telling the world what life under Sharia law is really like. First of all, there is no thinking, as Allah has provided all the answers to all questions. Second, there are no civil rights, and, third, women are esteemed slightly less than camels. The government does not reflect the voice of people but the voice of Allah, who must be some kind of nut. Get caught stealing and lose your right hand; have a child out of wedlock and be stoned to death. Does any Westerner need any more motivation to opposed Islamic terrorists than to know what their ultimate goals much less their means are? Just tell the truth about them.

Obviously, stupidity is the great ally of priests and political leaders when they fail to adjust their ideology to altered circumstances or fail to interpret their creed to a compelling need. Stupidity makes illogical interpretations both possible and acceptable. In times of challenge, when people are most in of need a credible cause, no one would be so stupid as to point out that the schema is a drawback and should be abandoned for a better one. However justified such an assertion might be, no religious leader could make such a self-defeating admission. If the schema can possibly be stretched to cover existing events, it will be. Be they religious creeds or secular laws, schemas are interpreted, rather than corrected, until the system breaks down. This occurs when unwelcome perceptions of cultural disintegration in the forms of violent riots, disruptive protests or massive emigrations cannot be denied even by the devout.

Not only can interpretation reduce a prevailing schema's meaning to irrelevance, but the emotional commitment of believers to a maladaptive schema can thwart the use and development of intelligence [49] and thus inhibit the adoption of one that is better suited to reality. The reaction of the holy Church to the inroads of science during the past several centuries is a stupendous example of how attempts to maintain a schema can inhibit development of control over the real world. The clergy were just trying to retain their influence among and power over faithful political leaders, but they therefore steadily had to renounce both as we gained knowledge and understanding about natural phenomena.

This commitment to God infected medical minds as well in the 14th century, when King Philip VI of France demanded an explanation from the faculty of the University of Paris for the Black Death then enveloping Europe. The answer then was that an angry God had ordained a fatal conjunction of the planets which had sucked up the water in the oceans creating a miasmic cloud which infected all who breathed it. According to English monks, God was miffed at the debauchery attending royal tournaments and specifically at the female cheerleaders who entertained the crowds between jousts [50]. Presumably, that explanation made it more difficult for natural scientists such as they were at the time to comprehend the role that fleas on rats played in the process.

Currently, the social sciences are directed toward rendering cultural phenomena comprehensible rather than just credible and finding PC solutions to them when possible. Most people, however, are emotionally involved with their established political, social and economic institutions. What most social scientists fail to appreciate is that they are studying sacred systems, tampering with people's beliefs and experiencing very much the same kind of rejection natural scientists like Copernicus, Galileo and Darwin experienced in ages past when they tried to help people understand the natural world.

One of the peculiar things about all religions, be they supernatural or superhuman, is that so much of their substance is demonstrably false. Nevertheless, religious beliefs are the driving force of society. People prefer to believe than know [51]. Facts and knowledge pale before the values of established beliefs and cherished attitudes. Norms sanctify behavior and certify social procedures as beyond question. Anyone who dares contradict, question or doubt enshrined cultural values is asking for ostracism or worse. No matter how society may falter, only cosmetic or comic criticism will be permitted. Any fundamental challenge to or questioning of basic assumptions will usually be dismissed out of hand as a threat from the outside. That America is not a democracy and that the alleged «Capitalistic» economy is government regulated by insiders who regulate the government mean naught to devoted flag wavers.

The basic problem with trying to reform religious institutions is that believers tend to discount mere factual knowledge. Facts are routinely refuted by information gathered by divination a method of gathering unavailable information, a means of learning the unknowable [52] and a source of considerable comfort and solace to those firmly committed to the prevailing religious belief system. This puts objective investigators at a disadvantage, as they accept the self limiting principle of confining themselves to verifiable data. Naturally, disturbing criticisms do not carry much weight with people entrenched in the holy establishment. These are more committed to themselves than to any principle of adjustment and thus tend to make any institution less and less efficient as justifiable complaints accrue unheeded with the passage of time. Indeed, as liberal theologian Adolf Hitler noted, "Religion is in perpetual conflict with the spirit of free research [53]." or, as any presumptuous mathematician might put it: Belief $\mathrm{x}$ Thinking=K. The more someone believes, the less he thinks and versa vicea: whatever the faith, religious fundamentalism is coupled to intellectual stagnation.

Fortunately for priests, beliefs are sustained by ritual rather than relevance. Ceremonial observances provide participants with what they perceive as means of influencing their relations 
with supernatural or superhuman powers that are believed to control all things. Usually, participation in rituals is intended to perpetuate or improve the believer's relation to such powers. Supplication is frequent and sacrifices explicit [54]. Naturally, anything good happening to the believer after prayers is attributed to them and acts (as did the food reward to Skinner's superstitious pigeons) as a reinforcement for the ritual.

Rituals not only strengthen the belief of the individual but also serve to promote group cohesion, since religious rituals are often social events. Although rituals are not designed to effect objective change directly, positive results may follow when an inspired believer or the united group copes with problems. Thus, rituals should not be judged as stupid for being misdirected at the time of performance; their value should be assessed later when the confident individual or cohesive group acts to deal with the pending intellectual challenges of the natural or cultural environments.

While we might tend to think of rituals in a purely theological context that is, in churches and similar institutions of spiritual beliefs they also play a significant role in secular religions. In American politics, for example, party platforms have taken on a metaphorical meaning, being increasingly ceremonial [55] expressions of and for the devout and decreasingly programs for future behavior [56]. People applaud and cheer them in perfunctory fashion, and perhaps some good comes out of all that later on, but the ritual is certain to be repeated four years later as much regardless as because of its direct or indirect, immediate or long range effects on political life.

If rituals are basically futile efforts to effect change in some direct and immediate sense, much of the criticism in Western societies could be considered ritualistic. First, criticism is often off the mark because it must be couched in language which inhibits accurate, relevant thinking about fundamental problems. Second, the people who are on the inside, know what is going on and could make relevant criticism are too much caught up in the system to put themselves in jeopardy by blowing whistles. Further, those on the outside usually have little influence and less power, so their expressed grievances may be safely ignored. Finally, although it is very nice that we can write our Congressman, send a letter to an editor or draft a useless book like this, anyone who thinks that valid criticism in such messages will have some positive effects probably also counts on winning the next Powerball jackpot.

Even when criticism is justified, witches or their human correlates may be targeted as convenient scapegoats by people unable or unwilling to acknowledge their own contribution to the creation of existing difficulties. Belief in witches and witchcraft is usually most intense in times of increased social tension when people are faced with a crisis they are unable to resolve by the institutional means which created it. Since witches cause misfortune, misfortune must be caused by witches, and there is nothing like a good witch hunt to permit a culture to express its frustration and release its righteous hostility on some hapless soul. This may be unfair, wrong, irrelevant and stupid, but it certainly is most satisfying to everyone (except the witches) [57]. Mostly, however, a witch hunt obscures the real causes of underlying problems and makes finding long term solutions less likely as energy and attention are misdirected toward the rituals of chasing, catching and disposing of people who were being themselves. You need not wonder where to look for our modern witches: our prisons are full of them.

They have been imprisoned because culture transmits behavior, beliefs and rituals across generations by the process of indoctrination. Not only do individuals learn certain forms of social or antisocial behavior, but groups each invariably pick up the notion that they are the one with superior values and which alone has a private line to the Almighty. People in other groups are judged, by some standard selected just for this purpose, to be less worthy than themselves [58]. This superiority complex must have been and may still be of survival advantage in intergroup competition, for groups with inferiority or realistic complexes are not notably common. Thus, the belief in superiority can realize itself by making believers in fact superior to those who doubt they are or know they are not. Obviously, this sense of superiority can run away with itself, cause a culture to overreach its limitations and, as happened with Nazi Germany, induce its own demise.

A slightly inflated sense of worth tempered by some sense of reality appears to be the common psychological state of most cultural groups, but even a modest sense of superiority usually is enough to make believers feel compelled to convert others to their better way of life. If conversion to the faith is impossible, the imposition of religious prohibitions is a worthy, secondary cause for a missionary [59]. It is difficult to imagine and impossible to calculate the misery presumably superior people have inflicted on others. Teaching by example is seldom enough. The presumption is to help the unwilling by forcing observance of rituals, proscribing behavior and attempting to impose beliefs on those unlucky enough to come into contact with moral if not intellectual superiority.

\section{References}

1. Hammond P (1978) An Introduction to Cultural and Social Anthropology. $2^{\text {nd }}$ ed. Macmillan; New York p.12.

2. Watson P (2011) The Great Divide. HarperCollins. New York, USA, p.23.

3. Critias Ca 410 BC Cited by S. Empiricus Ca 200 AD.

4. Critias Ca 410 BC Cited by Polybius Ca 150 BC.

5. Peterson Rev J (2003) SCAM. WND Books; Nashville, TN 59. Shaw G Cited in P McWilliams's Ain't Nobody's Business If You Do. Prelude Press; Los Angeles, CA. 1993. 568 Mr. Shaw refers specifically to the transfer of belief from God, who apparently sometimes thinks She is a doctor, to the actual, human medical profession. I am more general and in-clusive.

6. Holmes O (1882) Some of My Early Teachers. Medical Essays, 18421882, The Works of Oliver Wendell Holmes. Houghton Mifflin; Boston. 1892. Vol 9: 434. 
7. Hammond op cit 358 .

8. Spiro M (1952) Ghosts, Ifaluk, and teleological functionalism. American Anthropologist 54: 497-503.

9. Hammond op cit 326.

10. Gauguin P (1989) (Yes, the artist.) Undated quotation on page 3 of Fischer D Albion's Seed. Oxford University Press; New York, USA.

11. Erickson S (2006) Philosophy as a Guide to Living. The Teaching Company. Chantilly VA. 2006. Part 1: p. 149.

12. Roszak T (1993) Mar/Apr 1993. Sierra, 78, \#2, 59. Koheleth. 235 BC Ecclesiastes. 9:9. There is neither "knowledge, nor wisdom, in the grave whither thou goest." Nor stupidity. JFW

13. Reischauer R (1967) Early Japanese History, part A. Peter Smith; Gloucester MA P.11.

14. Bondi H (1979) Religion is a good thing. In The Encyclo-pedia of Delusions edited by R. Duncan and M. Weston-Smith. Wallaby, New York, USA.

15. Al-Razi A (1999) Ca 860. In: Straumsa S, Freethinkers of Medieval Islam. Brill. Leiden P.96.

16. Wells HG (1922) A Short History of the World. Chap XLIII.

17. Bronowski J (1973) The Ascent of Man. Little, Brown \& Co. Boston, MA, P.166.

18. Ibid P.184.

19. Gorka S (2016) Defeating Jihad. Regnery; WDC. 2016. 57-58. Notable among the War Verses are 9:5 and 29 which com-mand the faithful to kill infidels wherever they are found.

20. Pagden A (2013) The Enlightenment. Random House; New York. 2013. 412. To complicate matters, Shi'ites believe the archangel Gabriel goofed by delivering the holy message to Muhammad instead of to Ali (Gellner 124)

21. Levi Provencal E (1928) (Ed and trans) Documents inedits d'historie almohade. P. Geuthner; Paris, France. P. 2-3.

22. Ansary T (2009) Destiny Disrupted. Public Affairs, New York P.81.

23. Ibid 96-97.

24. Ibid 248.

25. Ibid 99.

26. Ibid $100 \mathrm{Eg}$, they knew the function of the heart and about circulation of the blood centuries before Harvey (102).

27. Ibid. 104.

28. Bronowski op cit pp.165-172.

29. Durant W (1950) The Age of Faith. Simon and Schuster. New York pp.179.

30. Sharani U (2006) Muslims Almost Totally De-pendent on Others, Says Mahathir. Muslim Institute. This was roughly the same time the Catholic Church was dealing with Galileo, making it a golden age of religious idiocy. In the West, rationalism won out; in the East, faith.

31. Watson P.A (2001) Terrible Beauty: The People and Ideas That Shaped the Modern Mind-A History. Phoenix San Diego, CA 755, USA.

32. Mansel P (2006) Constantinople, London, 45: pp.1453-1924.

33. Ferguson N (2011) Civilization: The West and the Rest. Penguin. New York, USA p.69.

34. Hammer J (2016) The Bad-Ass Librarians of Timbuktu. Sim-on \& Schuster, New York p.67.
35. Kalb C (2016) Andy Warhol Was a Hoarder. National Geo-graphic, WDC p.50.

36. Grayling A (2016) The Age of Genius. Bloomsbury New York pp.240.

37. Alwaki A (2008) A Question about the Method of Establishing of Khifala. Imam Anwar's Blog. an- pp. 232.

38. Rage Sheikh A (2011) Based on Somali's al Shabaab Vows to Avenge bin Laden. Reuters. Scahill pp.487.

39. Kraus P, Pines S (1998) al-Razi. The Encylopaedia of Islam 3. II Leiden, Netherlands pp.1913-1938.

40. Straumsa op cit p.98.

41. Ibid pp.103.

42. Hecht J (2003) Doubt: A History. HarperOne; New York. 2003. 229. Hinduism gets off easier for having just misled India into 1,000 years of defeat and stagnation, providing no means for interpersonal relations or political philosophy. It di-minishes people intellectually, failing to equip them for chal-lenges and stifling their psychological development. (Watson. op. cit. 762-763.) Hindu thought ground to a halt toward the end of the 13th century, beginning the Great Lethargy which continues to this day. (Paz. 89-90.) When it awakes, it will be, like Islam, in rage and revolt, (Naipaul. 518.) and a step was taken in that direction by Swami Vivekananda ca. 1900 when he called upon Hindus to eat beef, praying, "O Thou Mother of Strength, take away my weakness, take away my unmanli-ness, and make me a Man!" No one seem to pick up on this idea, but it is noteworthy that both Islam and Hinduism are in-different to the conservatism/liberalism duality of the West: Both major Eastern religions are committed to strong-willed super humans (Mishra. 244.)-i.e., suicidal nut cases.

43. Churchill W (1899) The River War. Col F Rhodes (ed.), Long-mans, Green and Co; London. pp. 248-249.

44. Clark H (1984) Publication of the Koran. Sixteenth Cen-tury Journal 15: $1-9$.

45. Scruton R (2015) Fools, Frauds and Firebrands. Blooms-bury, New York, pp.234.

46. Ansary op cit pp.209.

47. Rage, Sheikh A (2011) The Brundian Bloodbath. Propaganda video 32: 28. Scahill pp. 492.

48. Malik Gen S (1979) The Quranic Concept of War.

49. Schopenhauer A (1973) Religion: A Dialogue and Other Es-says. 1851. An essay published in Parerga und Paralipome-na: Kline Philosophische Schriften. Saunders T. Greenwood, Westport CT p.3-4.

50. Lacey R (2007) Great Tales from English History. Back Bay Books. New York, p. 132.

51. Wilson E (1975) Sociobiology. Harvard University Press; Cambridge, MA pp.561.

52. Hammond op cit pp.355.

53. Hitler A (2000) Hitler's Table Talk: 1941-1944. Edited by Hugh TrevorRoper. 2000. Enigma Books, London pp.353.

54. Hammond op cit pp.321.

55. Arnold T (1937) The Folklore of Capitalism. Yale University Press, New Haven, CT p.41.

56. Stevenson C (1938) Paraphrased in Means of Ascent by R. Caro. 1990 Vintage, New York pp.165.

57. Hammond op cit pp.353.

58. Bondi op cit pp.206.

59. Ibid. 
(C) (1) $\begin{aligned} & \text { This work is licensed under Creative } \\ & \text { Commons Attribution 4.0 License } \\ & \text { DOI: 10.19080/GJIDD.2018.04.555634 }\end{aligned}$
Your next submission with Juniper Publishers will reach you the below assets

- Quality Editorial service

- Swift Peer Review

- Reprints availability

- E-prints Service

- Manuscript Podcast for convenient understanding

- Global attainment for your research

- Manuscript accessibility in different formats

( Pdf, E-pub, Full Text, Audio)

- Unceasing customer service

Track the below URL for one-step submission https://juniperpublishers.com/online-submission.php 